\section{Emergency physician wins Giller Prize}

$I^{1}$ 'll admit it: I didn't think Vincent Lam, a first-time author, was going to win the 2006 Giller Prize for his Bloodletting \& Miraculous Cures. The prestigious Giller Prize, at $\$ 40000$, is Canada's largest prize for best Canadian novel or short story collection published in English. Smart money, according to the Globe and Mail, was on Rawi Hage's De Niro's Game. My friends and I thought Carol Windley's Home Schooling had the edge. I reviewed Lam's book months ago in the Canadian Medical Association Journal and, despite problems of characterization, I thought it quite good in parts - and it was especially good in conveying what it means to be a doctor, what it means to be responsible. But, to be fair, it did tackle love. And all the books that deserve to win prizes should do that.

I figured, too, that Lam would face discrimination by the Giller judges. After all, the MD often means an asterisk is attached to one's status as a writer; during post-Giller interviews he's doggedly repeated that he considers himself both a writer and a doctor, when asked which one he thinks of himself as first. One reporter asked him about his salary, and a host of reviewers and columnists have made the easy, obvious and ultimately erroneous assertion that his prose is reminiscent of an ER episode. (One can't, nowadays, write a story about medicine and avoid that comparison. But it can't help this view that his stories have been picked up for film.)

Lam quietly stated that his Giller win was a confirmation of the fact that he can be both doctor and writer - or writer and doctor, whichever comes first. He thought too that his career as a doctor gave him a special, privileged perspective upon patient's lives, a perspective that helped him formulate the "stories" he's made on paper, be they fictional or be they notes in a patient chart. Each complemented the other.

But what does this have to do with emergency medicine? Well, Lam's an emergency physician at Toronto East General. And his stories do sometimes centre on the emergency department and on a fictional emergency physician. Almost all have medicine as their engine. But it's a compliment to Lam that the setting is unimportant; what he's rendered are credible stories that happen to occur in hospitals and clinics. And what he's done is win the biggest literary prize in the land. He's the first doctor to have done so; and see, I didn't, nor will I, ever, string together "Michael Crichton" and "Vincent Lam" in a sentence.

Oops.

\section{Shane Neilson, MD}

Family physician

Erin, Ont.

\section{CMA editor extraordinaire retires}

$\mathrm{J}$ ennifer Raiche, an editor with CJEM's publishers, the Canadian Medical Association (CMA), has announced that she is retiring at the end of 2006. Jen has worked with CJEM from the beginning, helping Grant and his new editorial team establish policies and procedures, as well as prepare all articles for publication over the past 8 years. She has been a key player in establishing CJEM as a powerful voice for Canadian emergency medicine.

She has been an editor with the CMA for more than 20 years, and during her tenure there she has held many positions. Since the early 1990s, she has worked on a number of specialty journals, including our own CAEP Communiqué, CJEM, the Canadian Journal of Rural Medicine, Humane Medicine, the Canadian Journal of Respiratory Therapy, the Federation of Medical Women of Canada's FMWC Newsletter, and the Canadian Association of Radiologists Journal. She also held positions on the Canadian Medical Association Journal, including Assistant Editor, Book Review Editor, and Editor of the now-defunct "Encore" section of CMAJ.

While we all wish her well in her future travels, her keen editorial skills, her experience, her friendly presence, and her knowledge of the history of the journal will be deeply missed. 